\title{
Complete Molar Pregnancy in Postmenopausal Woman: A Rare Case Report
}

\author{
Sutrisno Sutrisno ${ }^{1}$ (D) Leny Farida ${ }^{2,3 *}$ (D) Defri Defri $^{4}$ \\ ${ }^{1}$ Department of Obstetrics and Gynecology, Division of Human Reproductive Endocrinology and Fertility, RSUD Saiful Anwar \\ Malang, Faculty of Medicine, Brawijaya University Indonesia, Malang, Indonesia; ${ }^{2}$ Department of Emergency, RSUD Raja \\ Ahmad Tabib, KEPRI Indonesia, Tanjung Pinang, Indonesia; ${ }^{3}$ Department of Obstetrics and Gynecology, Faculty of Medicine, \\ Brawijaya University Indonesia, Malang, Indonesia; ${ }^{4}$ Department of Obstetrics and Gynecology, RSUD Raja Ahmad Tabib, \\ KEPRI Indonesia, Tanjung Pinang, Indonesia
}

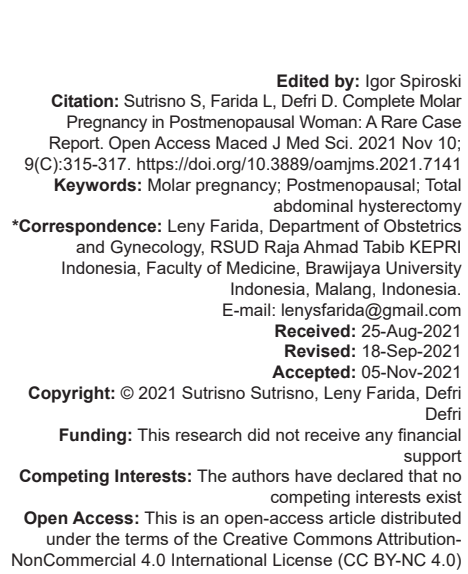

\section{Abstract}

BACKGROUND: Molar pregnancy, the form of the gestational trophoblastic disease (GTD), generally occurs in women of the reproductive age group, and rarely occurs in postmenopausal women. To present a rare case of molar pregnancy in a postmenopausal woman.

CASE REPORT: A multiparous woman aged 54 years was referred to the outpatient department at Raja Ahmad Tabib General Hospital of Riau Island, Indonesia with the main symptoms of nausea and vomiting profusely with 1 month before, lower abdominal pain, lump in the abdomen, abnormal vaginal bleeding, and a positive urine pregnancy test. Her last menstrual bleeding was 14 months ago. Physical examination found stable hemodynamic within blood pressure 150/95 mmHg. Laboratory results showed $\mathrm{Hb} 11.7 \mathrm{~g} / \mathrm{dL}$, positive urine pregnancy test, and serum $\beta$-HCG $292,876.1 \mathrm{mIU} / \mathrm{mL}$. Ultrasound examination showed a vesicular pattern in the uterine cavity without fetal tissue. The patient was managed by elective total abdominal bilateral hysterectomy salpingo-oophorectomy The intraoperative finding was softened, enlarged uterus size of 14-16 weeks of pregnancy, and no local spreading of disease. The patient was discharged on the 3 day after surgery.

CONCLUSION: Even though molar pregnancy is rare, it can occur in the postmenopausal woman. Therefore, GTD has remained in the differential diagnosis of postmenopausal bleeding which can prevent delay in diagnosis and management. Definitive treatment with total abdominal hysterectomy has been chosen in menopausal women who do not wish to preserve their fertility and prevent any malignant sequelae.

\section{Introduction}

Hydatidiform mole, also known as molar pregnancy, is a form of the gestational trophoblastic disease (GTD). Hydatidiform mole is caused by excess trophoblast tissue growing into abnormal masses and showing edema of the villous stroma. It is divided into complete moles and partial moles based on genetic and histopathological features [1]. A complete mole is usually diploid, consists of diffuse hydropic chorionic villi, and contains no fetal tissue, whereas a partial mole is usually triploid, often contains fetal tissues and a large placenta [1]. Mostly GTD is benign, but potentially turns to malignant which is known as gestational trophoblastic neoplasia, including invasive mole, choriocarcinoma, placental site trophoblastic tumor, and epithelioid trophoblastic tumor [2]. Approximately, $20 \%$ of complete moles turn to malignant transformation [2].

The prevalence of molar pregnancy is higher in Southeast Asia than in developed countries (North America, Australia, New Zealand, and Europe), accounting for 2/1000 pregnancies [3]. The other study found that Asians having a higher incidence compared with non-Asian (1/387 vs. 1/752 live births) [4]. In UK, molar pregnancy is a rare condition and estimated incidence of $1 / 714$ live births [4]. While in Indonesia, the prevalence of molar pregnancy is not known due to the lack of studies.

Complete molar pregnancy generally occurs in women in the reproductive years of age. However, several risk factors of complete molar pregnancy have been reported and the most established are extreme maternal age and previous molar pregnancy. The risk of complete molar pregnancy increases for women older than 40 years old [5]. Moreover, a history of failed pregnancy including elective abortion and miscarriage may increase the risk of molar pregnancy [6].

Complete molar pregnancy is usually diagnosed during the first trimester of pregnancy through ultrasound examination for the gold standard in noninvasive modality. The management depends on age and her desire to preserve fertility [7]

We present here a rare case report with complete molar pregnancy in a postmenopausal woman. 


\section{Case Report}

A 54-year-old woman was referred to the outpatient department at Raja Ahmad Tabib General Hospital of Riau Island, Indonesia with the main symptoms of nausea and vomiting profusely with 1 month before, lower abdominal pain, lump in the abdomen, abnormal vaginal bleeding, and a positive urine pregnancy test. Her last menstrual bleeding was 14 months ago. She had three normal births, one abortion needed curettage and dilatation procedure, and her last pregnancy was 12 years back. She had never taken neither contraceptive pills nor devices. She had a history of hypertension and continuing consumed oral antihypertension treatment.

Physical examination found stable hemodynamic within blood pressure 150/95 $\mathrm{mmHg}$. Laboratory results showed Hb $11.7 \mathrm{~g} / \mathrm{dL}$, leukocyte $20,900 / \mu \mathrm{L}$, platelet count $220,000 / \mu \mathrm{L}, \mathrm{FT} 40.79 \mathrm{ng} / \mathrm{dL}, \mathrm{TSH} 1.9 \mathrm{mIU} / \mathrm{mL}$, normal chest $\mathrm{X}$-ray, normal renal and liver function tests, positive urine pregnancy test, and serum $\beta$-HCG 292,876.1 mIU/mL. Ultrasound examination showed a vesicular pattern in the uterine cavity without fetal tissue (Figure 1). The patient was diagnosed with GIVP3A3 gravida within complete molar pregnancy. The patient was managed by elective Total Abdominal Bilateral Hysterectomy SalpingoOophorectomy. The intraoperative finding was softened, enlarged uterus size of 14-16 weeks of pregnancy, and no local spreading of disease. The patient was discharged on the 3 day after surgery.

\section{Discussion}

Pregnancy rarely occurs in women over 50 years old. Although, it can be occurred in the postmenopausal age group and may develop the GTD. Moreover, the postmenopausal age group has a higher incidence and usually turning malignant of GTD [8]. The incidence of GTD in women over 40 years old increases by 7.5 until 10 times [9]. Perimenopausal age has been involved in more severe conditions because their oocytes are more apt to unnatural fertilization [10], [11]. A previous study reported $25 \%$ of patients of women aged 50 or older were diagnosed with choriocarcinoma, 35\% with hydatidiform mole, and $40 \%$ with invasive mole [12]. The other study reviewed $28.4 \%$ of women aged 50 or older turning malignant disease, $47.7 \%$ benign moles, and the other $23.9 \%$ unclear pathological diagnosis [13].

The last menstrual bleeding of the patient was more than 1 year. According to the International Federation of Gynecology and Obstetrics, menopause is defined as when a woman no longer has menstrual periods for at least 1 year and after that is a postmenopausal stage [14]. Natural menopause

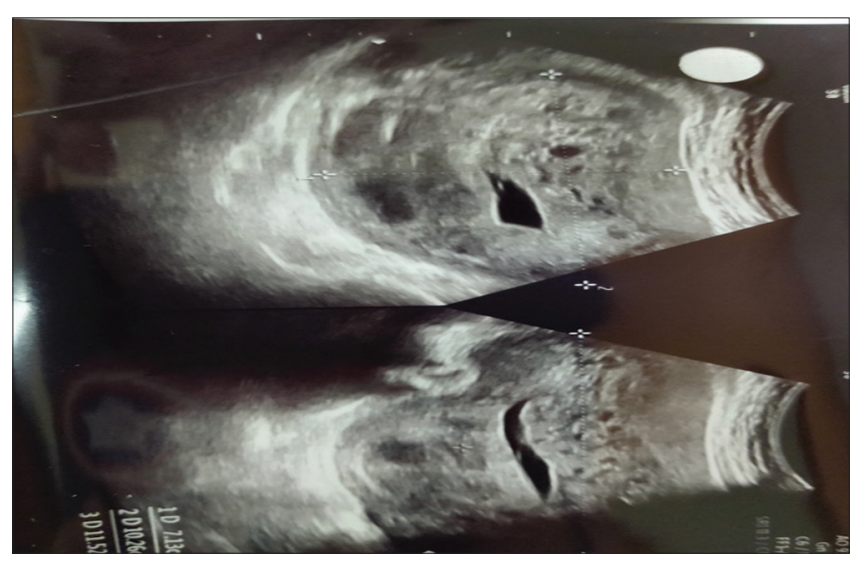

Figure 1: Ultrasound examination showed snowstorm appearance which was suggestive of hydatidiform mole

typically occurs in aged 50s. When the woman in the menopause stage, their follicles in the ovaries decrease and make less estrogen. Thus, ovulation becomes irregular because of an incompatible level of estrogen when reaching the induction of luteinizing hormone surge. Sometimes anovulatory cycles may be interspersed with ovulatory cycles. Although pregnancy in older age is fairly uncommon, when it occurs may develop GTD due to progressive loss of ovarian function and sporadic ovulatory cycles [14].

Identification of molar pregnancy in elder women is difficult because of unexpected conditions. Diagnosis is made by anamnesis, $\beta$-HCG serum levels, gynecologic examination, and pelvic ultrasonography. Molar pregnancy commonly presents with vaginal bleeding (46\%), excessive uterine size (24\%), and hyperemesis (14\%) [15]. Increasing $\beta$-HCG serum levels $>100,000 \mathrm{mlU} / \mathrm{mL}$ indicate excess trophoblast tissue growing and raise suspicion for a molar pregnancy [15]. In this case, the patient has an abnormality high level of $\beta$-HCG 292,876.1 $\mathrm{mlU} / \mathrm{mL}$. Ultrasound examination has been chosen for initial evaluation and remained the gold standard for imaging molar pregnancy. Commonly appeared of ultrasound is an enlarged uterus filled with a heterogenous predominantly echogenic mass with several hypoechoic foci, called snowstorm appearance [7]. The management of molar pregnancy depends on the patient's age and fertility preservation. Hysterectomy is particularly advisable for patients aged over 40 years [7]. Implicated to the high rate of malignant sequelae, total abdominal hysterectomy for the treatment of hydatidiform mole, in this case, was chosen that reasonable option for the patient who does not wish to preserve her fertility and prevents malignant Sequelae.

\section{Conclusion}

Even though molar pregnancy is rare, it can occur in the postmenopausal woman. Therefore, 
GTD has remained in the differential diagnosis of postmenopausal bleeding which can prevent delay in diagnosis and management. Definitive treatment with total abdominal hysterectomy has been chosen in menopausal women to prevent any malignant sequelae.

\section{References}

1. Cunningham FG, Williams JF. William Obstetrics. $23^{\text {rd }}$ ed. New York, USA: McGraw-Hill; 2012.

2. Bruce S, Sorosky J. Gestational trophoblastic disease. In: Stat Pearls. Treasure Island, FL: Stat Pearls Publishing; 2021. PMid:29261918

3. Lurain JR. Gestational trophoblastic disease I: Epidemiology, pathology, clinical presentation and diagnosis of gestational trophoblastic disease, and management of hydatidiform mole. Am J Obstet Gynecol. 2010;203(6):531-9. https://doi. org/10.1016/j.ajog.2010.06.073

PMid:20728069

4. Tham BW, Everard JE, Tidy JA, Drew D, Hancock BW. Gestational trophoblastic disease in the Asian population of Northern England and North Wales. BJOG. 2003;110:555-9. PMid: 12798471

5. Sebire NJ, Fisher RA, Foskett $M$, Rees $H$, Seckl MJ, Newlands ES. Risk of recurrent hydatidiform mole and subsequent pregnancy outcome following complete or partial hydatidiform molar pregnancy. BJOG. 2003;110(1):22-6.

PMid:12504931

6. Schorge JO, Schorge JO, Bradshaw KD, Halvorson LM, Schaffer JI, Corton MM. Williams Gynecology. New York, USA: McGraw-Hill; 2008

7. Cavaliere A, Ermito S, Dinatale A, Pedata R. Management of molar pregnancy. J Prenat Med. 2009;3(1):15-7.

PMid:22439034
8. Dhanapal M, Padmapriya P, Pandian A. A hydatidiform mole in a postmenopausal women. Int J Reprod Contracept Obstet Gynecol. 2018;7:2500-2.

9. Sebire NJ, Foskett M, Fisher RA, Rees H, Seckl M, Newlands E. Risk of partial and complete hydatidiform molar pregnancy in relation to maternal age. BJOG. 2002;109(1):99-102. https://doi. org/10.1111/j.1471-0528.2002.t01-1-01037.x

PMid: 11843379

10. Mangili G, Giorgione V, Gentile C, Bergamini A, Pella F, Almirante $G$, et al. Hydatidiform mole: Age-related clinical presentation and high rate of severe complications in older women. Acta Obstet Gynecol Scand. 2014;93(5):503-7. https:// doi.org/10.1111/aogs.12357

PMid:24575838

11. Mohammadjafari R, Abedi P, Najafabady MT. The gestational trophoblastic diseases: A ten year retrospective study. Cell J. 2010;4(1):1-4.

12. Tsukamoto N, Iwasaka T, Kashimura $\mathrm{Y}$, Uchino H, Kashimura M, Matsuyama T. Gestational trophoblastic disease in women aged 50 or more. Gynecol Oncol. 1985;20(1):53-61. https://doi. org/10.1016/0090-8258(85)90124-6

PMid:2981190

13. Jequier A, Winterton WR. Diagnostic problems of trophoblastic disease in women aged 50 or more. Obstet Gynecol. 1973;42(3):378-87.

PMid:4353348

14. Mehrotra $S$, Singh $U$, Chauhan $S$. Molar pregnancy in postmenopausal women: A rare phenomenon. BMJ Case Rep. 2012;2012:bcr2012006213. https://doi.org/10.1136/ bcr-2012-006213

PMid:22967678

15. Sun SY, Melamed A, Goldstein DP, Bernstein MR, Horowitz NS, Moron AF, et al. Changing presentation of complete hydatidiform mole at the New England trophoblastic disease center over the past three decades: Does early diagnosis alter risk for gestational trophoblastic neoplasia? Gynecol Oncol. 2015;138(1):46-9. https://doi.org/10.1016/j. ygyno.2015.05.002

PMid:25969351 